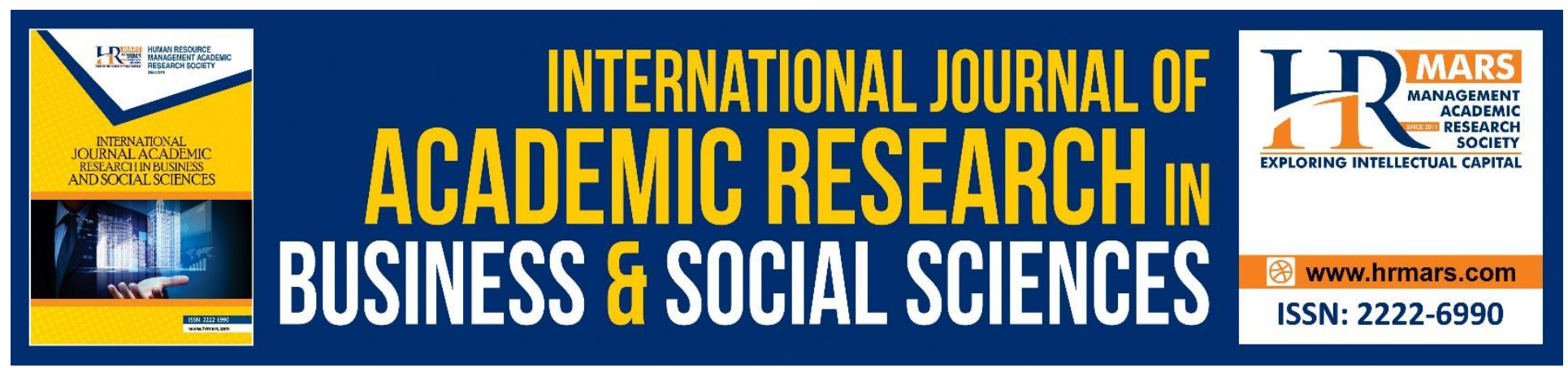

\title{
Exploring the Corollary of National Feelings on International Business Negotiations: A perspective of Tanzania Business practice
}

\author{
Burhan, Ahmad Mtengwa
}

Janeth Amaniel Malleo

To Link this Article: http://dx.doi.org/10.6007/IJARBSS/v8-i12/5415

DOI: $10.6007 /$ IJARBSS/v8-i12/5415

Received: 02 Nov 2018, Revised: 13 Dec 2018, Accepted: 21 Dec 2018

Published Online: 28 Dec 2018

In-Text Citation: (Burhan \& Malleo, 2018)

To Cite this Article: Burhan, A. M., \& Malleo, J. A. (2018). Exploring the Corollary of National Feelings on International Business Negotiations: A perspective of Tanzania Business practice. International Journal of Academic Research in Business and Social Sciences, 8(12), 2142-2159.

Copyright: (C) 2018 The Author(s)

Published by Human Resource Management Academic Research Society (www.hrmars.com)

This article is published under the Creative Commons Attribution (CC BY 4.0) license. Anyone may reproduce, distribute, translate and create derivative works of this article (for both commercial and non-commercial purposes), subject to full attribution to the original publication and authors. The full terms of this license may be seen at: http://creativecommons.org/licences/by/4.0/legalcode

Vol. 8, No. 12, 2018, Pg. 2142 - 2159

http://hrmars.com/index.php/pages/detail/IJARBSS

JOURNAL HOMEPAGE

Full Terms \& Conditions of access and use can be found at http://hrmars.com/index.php/pages/detail/publication-ethics 


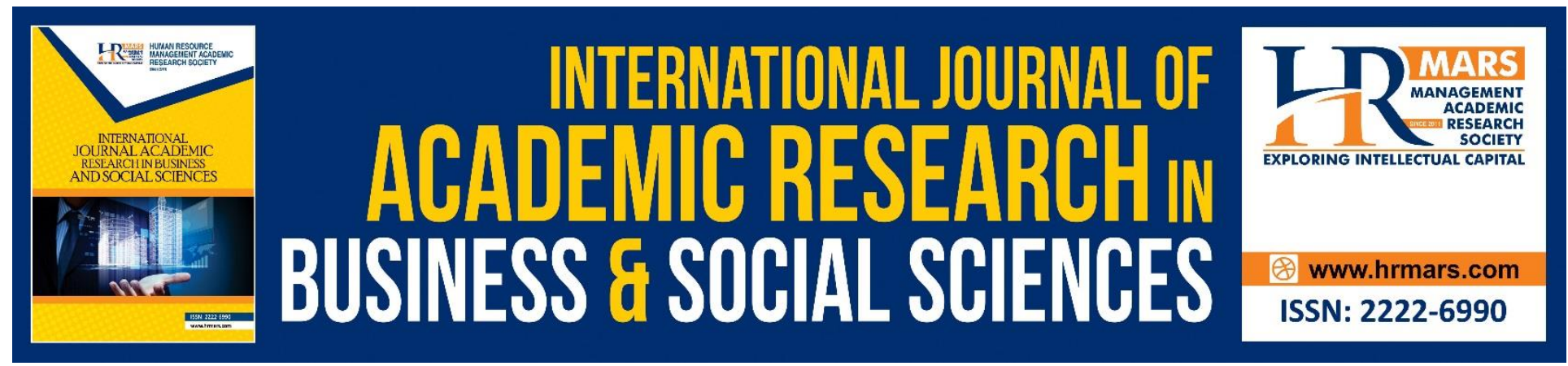

\title{
Exploring the Corollary of National Feelings on International Business Negotiations: A perspective of Tanzania Business practice
}

\author{
Dr. Burhan, Ahmad Mtengwa \\ Centre for Foreign Relations, Department of Economic Diplomacy, Po Box 2824 Dar es Salaam, \\ Tanzania. \\ Email: mtengwa@hotmail.com
}

Janeth Amaniel Malleo

Centre for Foreign Relations, Department of Economic Diplomacy, Po Box 2824 Dar es Salaam,

Tanzania.

Email: janee2malleo@gmail.com

\begin{abstract}
This paper aim to explore the practices of Tanzanian business negotiators during negotiation process. Specifically the paper aims to address the following; to explore the relationship between nationalism and practice of international business negotiations, to explore the relationship between national identity and practice of international business negotiations and to analyze the relationship between national pride and practice of international business negotiations.

The data are drawn from a survey of Tanzania business negotiators and analyzed by using multivariate analysis particular exploratory factor analysis. The results suggest that national feelings need to be taken into account by Tanzanian negotiators. Study come in concluding that national political interest, national development vision, foreign investor influences', negotiator's value, national interest precedence and national dignity has implication on national feeling for business negotiator.

This paper suggests that our supposition about national feelings might have enduring value, even though there is some evidence to suggest that Tanzania negotiating styles are changing.

Keywords: International Business Negotiations, National Feeling, Nationalism
\end{abstract}

\section{INTRODUCTION}

International business negotiations are defined as the deliberate interactions of two or more social parties with business goals and originating from different nations, who attempt to define or redefine their interdependence in a business matter. Tanzania business practitioners and 
government are making deliberate efforts to negotiate with either companies or multinational organizations or regional economic organizations or other government institutions on various business agenda. The negotiation process in Tanzania is done by various government agencies depending on the matter, and in collaboration with other stakeholders. The magnitude of international business negotiations has become one of main instrument to reach consensus on business deals between the parties.

Much has been written about the art and the practice of international business negotiating. The Tanzania environment, in particular, has attracted considerable attention in recent years, from both scholars and practitioners for instance, Burhan (2013), Burhan and Mihanjo (2013), Kamukwamba (2012). Despite vast increases in our knowledge about Tanzania business negotiating styles and practices, there may be underlying constructs that affect negotiating processes and business relationships. One of these issues is national feelings, which is the felt need to promote the best interests of the Mother Country above either personal or organizational concerns or needs. While Western negotiators likely are intent on obtaining the best "deal" for the corporation (Blackman, 1997; Chen, 1996; Eiteman, 1990; Pye, 1982), the Tanzania counterpart may be torn (either consciously or unconsciously) between, what might be, two incompatible forces - the need to serve the enterprise and the need to promote or protect the wider interests of the Motherland. Of course, these two sets of needs may not be in conflict; nonetheless, the Tanzania negotiator may have to consider an additional element at each stage in the negotiation process, further complicating an already intricate cross-cultural interaction. The Western negotiators also, may need to be more aware of undercurrents of national feelings. Sensitivity to this issue might increase success rates, decrease the time spent negotiating, or reduce misunderstanding.

Using data obtained from Tanzania business practitioner, this paper will explore concepts of national feelings from a Tanzania contextual perspective, as they relate to business negotiation processes and relationships. As pointed out by Burhan and Masele (2014) the dynamics of international business negotiations can refer to the way in which parties interact and relate in their business deals after agreement and signing of the contracts. The interaction can be looked at as situations of one of the parties or both behave towards obligations and agreed agenda after signing the contracts. The dynamic situations occur when parties fail to implement the agreement. According to Salacuse (1993), the challenge of international business negotiations exists not just in "getting to yes" but in trying to actually implement the agreement. The dynamics of international business negotiations are always stated after agreement as noted by Ghauri (1993) and Acuff (1993).

In recent years media and other pressure group mourn about investor's contract which a government has sign particular on mining sector and power purchase agreement. As observed by Kweka (2004) that a number of international trade agreements and negotiations, in both the multilateral and regional framework, their performance have been rather limited by a number of constrains in Tanzania context. It might be true that these constrain is the result of human aspect of behavior or lack of national feeling when business negotiator turn on the table. 
Challenges of international business negotiations exists not just in "getting to yes" but in trying to actually link national feeling and negotiation agenda up to the agreement.

Since negotiators are individual or human being they might have their own objective as well, but researchers argue that there is a need for negotiators to intervene national feeling on negotiation objective as supplemental by Shi and Wright (2002). In this study a national feelings is describe as a felt need to promote the best interests of the country or any other particular concern such as personal or organizational needs. In that regards the purpose of the study is to explore the practices of Tanzanian business negotiators whether they peruse national feeling during their negotiations.

Therefore, the intent of study is to explore the practices of Tanzanian business negotiators on whether they peruse national feeling during their negotiations. Specifically the paper aims to address the following; - (a) To explore the relationship between nationalism and practice of international business negotiations. (b) To explore the relationship between national identity and practice of international business negotiations. (c) To explore the relationship between national pride and practice of international business negotiations.

\section{RELATED LITERATURE REVIEW}

The success of international business relations depends on effective business negotiations. Business negotiations may be understood as encounters between firms or economic organizations with the goal of reaching agreements to derive economic benefits. Numprasertchai and Swierczek (2006) defined international business negotiations as the deliberate interaction of two or more social units (at least one of them a business entity) originating from different nations, and attempting to define or redefine their interdependence in a business matter. Alternative definition from Phatak \& Habbiy (1996) is that a global business negotiation is a process whereby two or more parties from different countries interact in a business deal with the goal of reaching an agreement. The business unit which establishes mutual relations could be a companycompany, company- government and solely interpersonal interactions over business matters such as sales, licensing, venture and acquisitions. Moreover, these parties may have common interests in various business transactions including the sale of a product to a foreign buyer, the promotion of a joint venture between two companies of different nationalities to share distribution channels in a third country, an acquisition or franchising.

When business practitioner are in session aspiring of achieve mutual goal each part is seeking to advance its interest with a reflection on negotiated objective. While both sides may have a common interest in working together, their interests will ordinarily conflict on a variety of individual issues affecting the relationship that they are trying to negotiate. As noted by Salacuse (2003) fundamental importance of business negotiator is to identify their interest, which can be based on organization objective on negotiation or as identifying on national interest of your company residence. At this point is where we argue that business negotiators whatever kind of interest they have but on national feeling in negotiation is paramount (Xinping and Philip 2010). 
Based on metal-analysis of Xinping and Philip (2010) much literature particular, empirical study on .... by, Blackman (19970); Pye (1982); Tung (1982 and 1994); Deverge (1986); Kirkbride, Tang, \& Westwood, (1991);Tse, Francis, \& Walls, (1994); Wagner \& Coll, (1994); Yang, (1998); Zhang, (1995) tends to neglect political, societal and ideological issues. In addition, many of the models have been developed in and for the North American context as observe by Graham, Mintu, \& Rodgers, 1994), although not to be discounted as valuable background, do not discuss macroenvironments in detail, a factor that is likely to have a large influence on negotiations, as the social or political backgrounds of the participants vary so significantly (Shi \& Westwood, 2000). As well, the effects of an exogenous culture or specific cultural factors have not been studied in detail (Shenkar \& Ronen, 1987; Xie, 1995). In reality no have negotiation models that reject the concept of maximum utility been widely considered (Wall, 1985; Lewicki, Litterer, Minton, \& Saunder, 1994). Thus, Western negotiators tend to concentrate on outcomes that measure success in terms of profitability, not national pride, or other societal issues (Paik \& Tung, 1999); (Graham 1996). Similarly, Tse, Francis and Walls (1994) suggest that the nature and the form of negotiating relationships, as well as societal norms, have not been studied in detail. These factors, along with the adaptive behaviors of negotiators, are likely to be extremely influential in determining negotiator behavior (Doktor, Tung, \&Glinow, 1991; Tung, 1994; Xie, 1995). Of note here, are Cavusgil and Ghauri's (1990), comments concerning "atmosphere", or "the relationship developed during the negotiation process between the parties". This concept in compasses both short- and long-term expectations as they relate to perceptions, or the "prospects" of reaching an agreement and primary objectives. In this paper, the acceptance and the understanding of national feelings would become part of this relationship building experience. Further, nationalism, was illustrated by Atkins (1996), and Child and Stewart (1997). National identity (Heiba, 1984) and national pride (Schlevogt, 2000),

This paper suggested that our suppositions about "national feelings" might have enduring value, even though there is some evidence to suggest that Tanzania negotiating styles are changing. As well, Kweka (2004) comment about Tanzanian commitment in negotiations, combined with Marie-Aude Fouéré (2014) and Nyerere (1974) give views on how both patriotism and socialism (uzalendo and ujama)" have been combined to create modern Tanzania business community, gave us further insights into the possible research directions on national feeling. In the same vein, Rodney (1971) and Shivji (1974) reflections about the widespread "sense of humiliation" felt by many Tanzania, along with the imperialism business structure "an evil imperialist power", lends credence to Tanzania to formulate their own unique business structure. Thus is in view of this paper that between 1960s to 1990s with the philosophy of socialism and self-reliance (siasa ya ujamma na kujitegemea) it is possible that the sense of national feeling was in utter for business negotiators at that period. The question is that in the 21 st century does this sense of national feeling still present on our business community.

Finally, we note that Tanzania has been regarded as possibly the toughest business environment in the margining market, this is because of the enormous intricacy of bureaucratic difficulties and corruption (Lofchie and Callaghy, 1995) and Nordic Consulting Group (NCG) report of 2010. As a 
result issues of honesty and truthfulness become strange practice on business negotiations. Thus we depict that for a business person to establish level of national feeling in corruption and bureaucratic situation is cumbersome. Possibility business negotiators might engage in deception to obtain advantage hence this might affect performance of negotiators in business deal. Thus, this paper describes a concept of national feeling for business negotiator as a sensitivity of parties toward devotion on national interest in any aspect of negotiation agenda. Despite the contribution of Xinping and Philip (2010) on national feeling, still there is little evidence of an empirical approach to the impact of national feelings on international business negotiations.

\section{METHODOLOGY}

\section{Research Design}

Many elements are common across research designs, whatever ontological and epistemological presuppositions inform the specific work. But these seemingly common elements can mask significant differences in approaches to research. We engage here interpretive research designs. Interpretive methodology has been widely applied to interdisciplinary research over recent decades.

The purpose of interpretive inquiry is to gain an understanding of human experience through establishing the meanings of phenomena. Also, its intention is objectively to interpret the meanings of phenomena that hide behind expressions of experience. Interpretive researchers believe that the reality to consists of people's subjective experiences of the external world; thus, they may adopt an inter-subjective epistemology and the ontological belief that reality is socially constructed.

According to Willis (1995) interpretivists are anti-foundationalists, who believe there is no single correct route or particular method to knowledge. Walsham (1993) argues that in the interpretive tradition there are no 'correct' or 'incorrect' theories. Instead, they should be judged according to how 'interesting' they are to the researcher as well as those involved in the same areas. They attempt to derive their constructs from the field by an in-depth examination of the phenomenon of interest. Gephart (1999argues that interpretivists assume that knowledge and meaning are acts of interpretation, hence there is no objective knowledge which is independent of thinking, reasoning humans. Myers (2009) argues that the premise of interpretive researchers is that access to reality (whether given or socially constructed) is only through social constructions such as language, consciousness and shared meanings. Interpretive paradigm is underpinned by observation and interpretation, thus to observe is to collect information about events, while to interpret is to make meaning of that information by drawing inferences or by judging the match between the information and some abstract pattern (Aikenhead, 1997). It attempts to understand phenomena through the meanings that people assign to them (Deetz, 1996). Observation from literature review suggests that national feelings are a contextually rich and essentially noticeable construct that may emphasize the Tanzanian negotiator's rational view, affecting both decision making and relations during negotiations. We argue that to understanding national feeling of negotiator in business transaction need interpretive paradigm since it will make possible for understanding the world as it is from subjective experiences of individuals. In that due the study of national feelings falls into the interpretative category, firstly, the concept resides in the Tanzanian negotiator's mind; secondly, there appear to be few similar variables discussed in previous studies; and thirdly the objective of this study is to capture the 
complexity and the subjectivity inherent in Tanzanian negotiators' thinking about national feelings.

\section{Data and Instrument of Measurement}

The nature of such interpretative research requires that data gathered from respondents focus on the respondents' (Tanzanian business negotiators') concerns. Data needs to be gathered within the managers as negotiators schema of thoughts, not the researchers (Harris, 2000:756). This methodological stance originated from the "emic" approach to international studies as observed by Pike, (1967), Berry (1969), Triandis, Vassiliou V, Vassiliou G, Tanaka, \& Shanmugan (1972), Brislin (1983) and Hall (1986).

Based on objective of the study the 19 items chosen for our study all relate to issues discussed on literature the data for this paper were drawn from a questionnaire developed to delineate the self-perceived characteristics of national feelings among Tanzanian business negotiators. Using work by Shi and Westwood (2000), a 146-item questionnaire was developed, of which 19 items appeared to pertain to the national feelings issue and adopted by this study. The selection or 19 items appear to be confirmed as appropriate measured concept as proposed by other scholar and researcher such as;- Heiba (1984) national interest, Phatak and Habib (1996) and Lavin (1994) political issues, Schlevogt (2000) national interest and dignity, Mayfield, Mayfield and Martin (1998) personal gains and losses, Paik and Tung (1999) competition for profit, Shenkar (1993) social values and Shi and Westwood (2000) government co-ordination.

A structural survey was used to correct ordinal data and respondents were asked to respond on Liker scale of measurement of five-point scale ranging from $1=$ strong disagree to $5=$ strong agree was developed to test negotiators' perceptions about national feelings. On our 19 items chosen for our study all relate to issues discussed previously by other authors. Thus, our work exhibits face validity (Patton, 1982, 1999), as well as being grounded in the literature. The sampling frame consisted of a list of over 110 Tanzanian business practitioners.

\section{Data Analysis}

Data were analyzed by using multivariate analysis in order to establish variable which constitute more explanation of the study. Factor analysis is a multivariate statistical method used to examine how underlying constructs influence the responses on a number of measured variables. According to Zikmund and Babin (2007:608) factor analysis is a technique for statistically identifying a reduced number of factors from a larger number of measured variables. The essential point in factor analysis is that, factors are not measured, but are identified by forming a variety of measurable variables. This means that in factor analysis, dependent and independent variables are not distinguished during the process of factor analysis. According to Zikmund (1994) the statistical purpose of factor analysis is to determine linear combinations of variables that aid in evaluating the interrelationships. 


\section{RESULT AND DISCUSSION}

\section{Demographic Characteristics}

This analysis presents uneven distribution of gender of respondents used in the study. Male respondents were $58.2 \%$ while females were $40 \%$ slightly lower than males. Also age groups of respondents differed a lot as age groups from 18-29 and 30-41 were highly represented compared to age groups of 42-53 and 54-65. To justify this difference in age of respondents, students appeared by $67 \%$ compared to other sectors. Other sectors included government officials (11\%), business communities (10\%) and other stakeholders (22\%). In addition, since many respondents were young people, even their involvement in business negotiations was minimal. Most of the respondents (88\%) have only participated in 1 to 3 business negotiations, followed by 4 to 5 times (15\%), and more than 9 times (5\%). Table 1 below presents the overall distribution of demographic information.

\section{1: composition of the respondents in demographic terms}

\begin{tabular}{|c|c|c|c|}
\hline Demographic & Rage & Frequency & $\begin{array}{l}\text { Percentage } \\
(\%)\end{array}$ \\
\hline \multirow[t]{3}{*}{ Gender } & Male & 44 & 40.0 \\
\hline & Female & 64 & 58.2 \\
\hline & Total & & \\
\hline \multirow[t]{5}{*}{ Age } & $18-29$ & 60 & 54.5 \\
\hline & $30-41$ & 38 & 34.5 \\
\hline & $42-53$ & 10 & 9.1 \\
\hline & $54-65$ & 1 & .9 \\
\hline & Total & & \\
\hline \multirow[t]{5}{*}{ Sector } & Tanzania Government officer & 11 & 10.0 \\
\hline & Tanzania business community & 10 & 9.1 \\
\hline & Student & 67 & 60.9 \\
\hline & Other & 22 & 20.0 \\
\hline & Total & & \\
\hline \multirow[t]{5}{*}{ Involvement } & $1-3$ times & 88 & 80.0 \\
\hline & 4-6 times & 15 & 13.6 \\
\hline & $7-9$ times & 2 & 1.8 \\
\hline & more than 9 times & 5 & 4.5 \\
\hline & Total & & \\
\hline
\end{tabular}

Source: Research findings, 2015

\section{Variable Description}

There are three main variables in this study namely Nationalism (national), National identity (value) and National pride (interest) since in each variable series of statement was developing to measure respondent perception on national feeling during negotiations process. Using likert scale enabled researcher to get an overall measurement of a contributing variable (Likert 1932). Thus perception of Tanzania business practitioner was measure on ordinal scale level of five- 
point likert scale i.e., 1=Strongly Agree, 2=Agree, 3=Neutral, 4=Disagree and 5=Strongly Disagree (Bowling 1997 and Burns \& Grove 1997). The study collected primary data from 110 business practitioner and other stake holder in Dar es Salaam city of Tanzania.

\section{Descriptive Statistics}

According to Trochim, (2006) a descriptive statistics are used to describe the basic features of the data in a study, with the purpose to present quantitative descriptions in simple summaries about the sample and the measures of the study in a sensible way. In descriptive statistics data set a measure commonly by measure of central tendency and measure of variability or dispersion. Babbie (2009) explain further Measures of central tendency include the mean, median and mode while measures of variability include the standard deviation (or variance), the minimum and maximum values of the variables, kurtosis and skewness. From table 3.2 bestow information regarding study variable Nationalism (national), National identity (value) and National pride (interest) The data presented in sensible way based on the mean score and standard deviation. Below is the table summary.

Table 3: Descriptive Statistics for Each Variable

\begin{tabular}{|l|l|l|}
\hline VARIABLE & MEAN & STANDARD DEVIATION \\
\hline Nationalism (national) & 19.46 & 7.644 \\
\hline National identity (value) & 21.36 & 7.566 \\
\hline National pride (interest) & 16.58 & 6.102 \\
\hline
\end{tabular}

Source: Research findings, 2015

\section{Correlation and Kaiser-Meyer-Olkin (KMO)}

According to Wang (2009) correlation measure the strength bi-variate linear relationship of the variables. The correlation coefficient for each pair of variables is given by the correlation matrix (R-matrix). The purpose of correlation is to discover if there strong or weak; positive or negative relations between variables. As noted by Hair (2009) the value of correlation can ranges between -1 and +1 . This means that, the values closer to either -1 or +1 indicate either strong negative or positive relationship respectively; also values closer to zero indicate weak relationship. But degrees of caution have to be establishing since problem of multicollinearity may exist, once variables have very strong relationship (Robert 1975 and Ned Kock and Gary S. Lynn (2012). This problem hinders effective estimation in factor analysis. So caution is required in the correlation analysis since correlation is the basis for factor analysis. 
Table 3: Correlation Matrix for Ministered Variable

\begin{tabular}{|c|c|c|c|c|c|c|c|c|c|c|c|c|c|c|c|c|c|c|c|}
\hline \multicolumn{6}{|c|}{ Nationalism nation } & \multicolumn{7}{|c|}{ National identity (value) value } & \multicolumn{7}{|c|}{ National pride (interest) intrst } \\
\hline & I1 & 12 & 13 & 14 & 15 & & V1 & V2 & V3 & V4 & V5 & V6 & & N1 & N2 & N3 & N4 & N6 & N5 \\
\hline \multirow[t]{2}{*}{ I1 } & 1.000 & 0.332 & 0.09 & 0.3 & 0.2 & $\mathbf{V}$ & 1.00 & 0.29 & 0.25 & 0.07 & 0.10 & 0.12 & N1 & 1.00 & 0.273 & 0.260 & -.218 & 0.104 & 0.33 \\
\hline & & & 6 & 20 & 99 & 1 & 0 & 1 & 3 & 0 & 0 & 2 & & 0 & & & & & 0 \\
\hline \multirow[t]{2}{*}{12} & 0.332 & 1.000 & 0.11 & 0.2 & 0.2 & $\mathbf{V}$ & 0.29 & 1.00 & 0.24 & 0.26 & 0.08 & 0.27 & N2 & 0.27 & 1.000 & .060 & 0.19 & - & 0.09 \\
\hline & & & 1 & 19 & 25 & 2 & 1 & 0 & 7 & 1 & 2 & 0 & & 3 & & & 0 & 0.066 & 5 \\
\hline \multirow[t]{2}{*}{13} & 0.096 & 0.111 & 1.00 & 0.4 & 0.2 & V & 0.25 & 0.24 & 1.00 & 0.14 & 0.12 & 0.21 & N3 & 0.26 & 0.060 & 1.000 & 0.05 & 0.186 & 0.28 \\
\hline & & & 0 & 51 & 08 & 3 & 3 & 7 & 0 & 5 & 7 & 7 & & 0 & & & 3 & & 6 \\
\hline \multirow[t]{3}{*}{14} & 0.320 & 0.219 & 0.45 & 1.0 & 0.3 & $\mathbf{V}$ & 0.07 & 0.26 & 0.14 & 1.00 & 0.16 & 0.50 & N4 & - & 0.190 & 0.053 & 1.00 & 0.155 & - \\
\hline & & & 1 & 00 & 35 & 4 & 0 & 1 & 5 & 0 & 6 & 1 & & 0.21 & & & 0 & & 0.04 \\
\hline & & & & & & & & & & & & & & 8 & & & & & 0 \\
\hline \multirow[t]{5}{*}{15} & 0.299 & 0.225 & 0.20 & 0.3 & 1.0 & $\mathbf{V}$ & 0.10 & 0.08 & 0.12 & 0.16 & 1.00 & 0.44 & N5 & 0.10 & & 0.186 & 0.15 & 1.000 & 0.07 \\
\hline & & & 8 & 35 & 00 & 5 & 0 & 2 & 7 & 6 & 0 & 1 & & 4 & 0.066 & & 5 & & 8 \\
\hline & & & & & & V & 0.12 & 0.27 & 0.21 & 0.50 & 0.44 & 1.00 & N6 & 0.33 & 0.095 & 0.286 & - & 0.078 & 1.00 \\
\hline & & & & & & 6 & 2 & 0 & 7 & 1 & 1 & 0 & & 0 & & & 0.04 & & 0 \\
\hline & & & & & & & & & & & & & & & & & 0 & & \\
\hline
\end{tabular}

Source: researcher's field data analysis, 2015 
As shown from the table above, correlation coefficients among observed National variables indicated no multicollinearity problem. No values were strongly correlated to hinder factor analysis. For the case of Value variable, the table above indicates no values which are highly correlated to pose the problem of multicollinearity during estimation. All variables correlate fairly. Table 3.4 above indicates that all variables correlate fairly and there is no sign of multicollinearity problem in our data regarding Interest variable.

For sample adequacy analysis, Kaiser-Meyer-Olkin (KMO) and Bartlett's test of sphericity were employed. KMO values range between 0 and 1 . Values closer to 0 indicate that factor analysis is inappropriate. For the case of Bartlett's test, existence of an identity matrix in our correlation matrix is tested. The identity matrix occurs when each pair of variables indicates zero correlation.

Table 4: KMO and Bartlet Test for Ministered Variable

\begin{tabular}{|l|l|r|r|r|}
\hline \multicolumn{2}{|l|}{ KMO and Bartlett's Test } & Nation & Values & Interest \\
\hline $\begin{array}{l}\text { Kaiser-Meyer-Olkin Measure of Sampling } \\
\text { Adequacy. }\end{array}$ & KMO & 0.485 & 0.636 & 0.667 \\
\hline Bartlett's Test of Sphericity & $\begin{array}{l}\text { Approx. Chi- } \\
\text { Square }\end{array}$ & 55.177 & 85.102 & 60.780 \\
\cline { 2 - 5 } & Df & 15 & 15 & 10 \\
\cline { 2 - 5 } & Sig. & 0.000 & 0.000 & 0.000 \\
\hline
\end{tabular}

Source: Researcher's field data analysis, 2015

The table above indicates KMO and Bartlett's test for all variables. Nation variable indicates KMO value of 0.485 which is a little bit good but still can perform factor analysis. KMO values for the two remaining variables were perfect for factor analysis. Regarding Bartlett's test of Sphericity, all values were significant indicating that our factor model is correct.

\section{Reliability Measure of Variables}

To ensure reliability of the data used for the study, this analysis employed Chronbach's Alpha coefficient measurement which indicates internal consistence of the data. Coefficients greater than 4 were regarded as adequate. As seen on table 3.5 below, all variables received good Alpha coefficients and they were all reliable and qualified for Component Factor Analysis.

Table 5: Cronbach's Alpha Reliability Measure for All Variables

\begin{tabular}{|r|c|r|c|}
\hline Variables & N of Items & N of observations & Cronbach's Alpha \\
\hline Nation & 6 & 110 & 0.446 \\
\hline Value & 6 & 110 & 0.627 \\
\hline Overall Alpha & 5 & 110 & 0.635 \\
\hline
\end{tabular}

Source: Researcher's field data analysis, 2015. 
INTERNATIONAL JOURNAL OF ACADEMIC RESEARCH IN BUSINESS AND SOCIAL SCIENCES Vol. 8, No. 12, Dec, 2018, E-ISSN: $2222-6990$ C 2018 HRMARS

\section{Component Factor Analysis}

Factor analysis is a multivariate statistical technique for data reduction. It compresses sets of complex data without losing data integrity, to form reduced set of factors, which are assumed to represent the observed variables under consideration. Gorsuch (1983:4) mote that factor analysis helps reduce a number of variables to a meaningful, interpretable and manageable set. In this study factor analysis will be used to establish whether the variables: Nationalism (Nation) National identity (value) and National pride (Intrst). Therefore, all factor loadings must be statistically significant at a minimum to confirm the discriminant validity of the measuring instrument used in the study. In this study, the sample size was 50 which are confirmed by Camrey and Lee (1992), Garson (2008) and Noruis (2005) in terms of the factor analysis sample size rule on number of constrain. In this study, the principalcomponent exploratory factor analysis with the support of statistical package SPSS 17.0 was adopted so as to obtain sound and clean solutions for our problem. Below is the table 3.6 shown result of factors analysis.

Table 6: Factor Loadings on Corollary Of National Feelings On Intentional Business A Perspective of Tanzania

\begin{tabular}{|c|c|c|c|c|}
\hline \multirow[t]{2}{*}{ Latent Variable } & \multicolumn{4}{|c|}{ Component Factor Analysis } \\
\hline & Factor 1 & Factor 2 & \multirow{2}{*}{\begin{tabular}{|l|} 
Factor 3 \\
Business \\
Political \\
\end{tabular}} & \multirow[t]{2}{*}{ Communalities } \\
\hline Nationalism & $\begin{array}{l}\text { National political } \\
\text { interest }\end{array}$ & $\begin{array}{l}\text { National } \\
\text { development } \\
\text { vision }\end{array}$ & & \\
\hline nation1 & 0.839 & & & \\
\hline nation6 & 0.704 & & & \\
\hline nation2 & & 0.789 & & \\
\hline nation4 & & 0.741 & & \\
\hline nation5 & & & 0.912 & \\
\hline \multirow[t]{2}{*}{ National identity (value) } & Factor 1 & \multicolumn{2}{|l|}{ Factor 2} & \\
\hline & $\begin{array}{l}\text { foreign investor } \\
\text { influences' }\end{array}$ & \multicolumn{2}{|c|}{ negotiator's value } & \\
\hline value6 & \multirow{2}{*}{0.854} & & & \\
\hline value4 & & & & \\
\hline value5 & 0.683 & & & \\
\hline value1 & & & 0.772 & \\
\hline value2 & & & 0.680 & \\
\hline value3 & & & 0.657 & \\
\hline \multirow[t]{2}{*}{ National pride (interest) } & Factor 1 & \multicolumn{2}{|l|}{ Factor 2} & \\
\hline & $\begin{array}{ll}\text { national interest } \\
\text { precedence }\end{array}$ & & national dignity & \\
\hline intrst1 & 0.786 & & & \\
\hline intrst2 & 0.758 & & & \\
\hline intrst5 & 0.524 & & & \\
\hline intrst3 & & & 0.880 & \\
\hline intrst4 & & & 0.767 & \\
\hline
\end{tabular}

Source: Researcher's field data analysis 2015. 
The component factor analysis result shown in table 6, reveals that two of the five item (nation 1 and nation6,) expected to measure nationalism have been loading in factor one (1) This means that respondents viewed these items as measure of a single construct renamed as and labeled National Political Interest. Further result reveals that two of the five item (nation2 and nation4) expected to nationalism have been loading in again factor two (2) This means that respondents viewed these items as measure of a single construct renamed as and labeled National development vision, observation show that some of the negation have association with national vision that why they focus on lo $\mathrm{g}$ term plan of the country economy. And last result that only one of the seven item (nation5) expected to measure nationalism have been loading in factor three (3) This means that respondents viewed these items as measure of a single construct renamed as and labeled Business Political, observations from study show that most of Tanzania business negotiators conduct their negotiation under certain administrative authority. Also communalities on all variables are considered to be more that $60 \%$. Observation from Tanzanian business practitioner on business negotiation as predicated on a number of factors in particular.

The component factor analysis result shown in table 6, reveals that three of the six item (value6,value5 andvalue4) expected to measure national identity have been loading in factor one (1) This means that respondents viewed these items as measure of a single construct renamed as and labeled foreign investor influences'. Further analysis reveals that six of the seven item (value1,value2 and value3 lexpected to measure national identity have been loading in factor two (2) This means that respondents viewed these items as measure of a single construct renamed as and labeled negotiator's value. Also communalities on all variables are considered to be more that $60 \%$. Observation from Tanzanian business practitioner on business negotiation as predicated on a number of factors in particular.

The component factor analysis result shown in table 6, reveals that six of the seven item (intrst1, intrst2 and intrst5) expected to measure national pride have been loading in factor one (1). This means that respondents viewed these items as measure of a single construct renamed as and labeled national interest precedence. Further analysis reveals that six of the seven item (intrst3 and intrst4) expected to measure national pride have been loading in factor two (2) This means that respondents viewed these items as measure of a single construct renamed as and labeled national dignity. Also communalities on all variables are considered to be more that $60 \%$. Observation from Tanzanian business practitioner on business negotiation as predicated on a number of factors in particular.

\section{MANAGERIAL IMPLICATION AND CONCLUSION}

Although aware of Weiss' (1994) admonitions concerning the undesirability of generalizing from a judgmental sample, it is felt that potentially, we have isolated an important construct that can affect international business negotiations. Further research will be necessary to verify our findings and to determine exactly how national feelings affect Tanzania negotiating styles, but if the results of this study are validated, Western negotiators may need to modify both preparation and negotiation styles. First, the rhetoric of negotiating may need to be modified to include verbal recognition of the national feelings issue. Even when in the cut and thrust of negotiating "the deal", the Westerners must learn to be flexible, as the term "profitability", for example, needs to be juxtaposed with terms that show intent to further the national good. It must be realized that the Tanzania counterpart might 
be torn between competing loyalties. The Western preoccupation with making "the deal", (Blackman, 1997; Pye, 1982), be tempered, therefore, as the Tanzania side might have a wider picture in mind. As well, it would be unwise to underestimate the depth of these feelings toward the Motherland. As the intense reaction to the 1976 of the Idi Amini Dada forces invasions in northern part of Tanzania in Kagera region illustrated, national dignity and pride appear to be an integral part of the Tanzania culture and psyche. Our findings, both nationally and regionally, strongly support this concept. Indeed, this research might add a new tactic to the Westerner's negotiating repertoire. As it has been suggested that Tanzania negotiators are strongly aware of national feelings, in some instances, perhaps objections or requests to modify proposals can be countered by suggesting that the alternative would serve the country less well than the original. A proposal that would weaken an organization, for example, might be met with arguments that national interests are not served if there isn't sufficient profit to modernize, or to send staff abroad for training. In general, knowing the other side and developing appropriate personal relationships, are important aspects of any negotiating process. This research will enable the Western negotiator to probe more effectively for answers as to why delays occur and for the reasons behind objections to negotiating positions, as nationalistic issues can be avoided, or couched in terms that are culturally sensitive.

In addition, understanding one's self, also is an integral part of successful negotiating. From the Tanzania perspective, the realization that national feelings (either conscious or subconscious) might affect negotiations, also needs to be considered. Questions concerning national pride and their effect on negotiation outcomes need to be asked. From a Western viewpoint, a general understanding of how the project might fit into national or provincial development plans can be valuable, as negotiations can then be couched in terms that fit into a broad national or regional framework. Therefore, promotion of the common good-e.g., training Tanzania nationals, technology transfer, access to foreign connections and relationship networks-should always remain part of the negotiator's repertoire, especially as they relate to specific regional concerns.

Our data indicate too, that the local authorities are likely to be briefed on the negotiations. This aspect of nationalism brings an additional "player" to the negotiating table (albeit vicariously), suggesting that relationship building needs to extend beyond the corporate realm. One can argue, however, that they will exists to separate national feelings from economics. Again, as the Idi Amini dada forces invaded in Kagera region illustrated, even during the height of the demonstrations, American-owned factories remained untouched. Komba (1993), has suggested, it is possible for Tanzania nationals to live with unavoidable inconsistencies, as they are accustomed to contradictions between "their private cognitions or opinions and their public behaviour". Thus, cognitive dissonance does not apply to the Tanzania culture.

Perhaps one approach, for the Westerners, would be to break the negotiation preparatory phase into two distinct parts: micro and macro. The micro phase would consider only the short-term economic/social aspects of the proposed negotiations; the macro part would place these negotiations within the wider "national good" perspective. These materials then must be combined (not presented separately), so the negotiating stance fits the more holistic Tanzania negotiating perspective (Graham, 1996). Indeed, the Western negotiator should be prepared to discuss several items simultaneously, as well as adjusting to a longer-term time horizon (Paik \& Tung, 1999). As with the Western negotiator, the Tanzania counterpart can use national feelings as a negotiating tool. 
Long known as tenacious negotiators, with endless patience (Shenkar, 1993; Tung, 1996), demands can be made to modify proposals, if they do not promote the national interest. As with others, this tactic should not be used spuriously, or negotiations could be seriously compromised.

Although the results of this study need to be verified through further research, it is suggested strongly that our findings can be translated into useful tools for both Western and Tanzania business negotiators. By isolating, and then showing the strength of national feelings among Tanzania negotiators and then illustrating that they are aware of national dignity and pride during the negotiating process, we have added a new dimension to international business negotiations. In addition to the national perspective, the study suggests that Tanzania is not a monolithic whole, but rather a collection of, often distinct, regions. Again, business negotiators, both Western and Tanzania, need to be aware that tactics used in one area might not be appropriate in another.

Respondents from Tanzania business practitioner seemed to exhibit a higher level of national feelings than interested in personal benefits. The lesson from Western negotiators is know your country (Atkins, 1996; Graham, 1996; Child \& Stewart, 1997).

\section{REFERENCES}

1. Aikenhead, G. (1994). The social contract of science: implications for teaching science. In J. Solomon \& G. Aikenhead (Eds.), STS education: international perspectives on reforms (pp. 1120). New York

2. Babbie, E. R. (2009). The Practice of Social Research (12 ${ }^{\text {th }}$ Ed.). Wadsworth.

3. Bartlett, M. S. (1937). Properties of Sufficiency and Statistical Tests. Proc. Roy. Soc. London Ser. (160) 268-282.

4. Berry, J. W. (1969). On cross-cultural comparability. International Journal of Psychology, 4, 119-128.

5. Blackman, C. (1997). Negotiating China: Case studies and strategies. Australia: Allen \& Unwin.

6. Blackman, C. (1997). Negotiating China: Case studies and strategies. Australia: Allen \&

7. Bowling, A. (1997). Research Methods in Health. Open University Press, Buckingham

8. Burhan, A.M. (2013). Marketers' perceptions of negotiation behavior in a global firm. DBA., Thesis

9. Burhan, A. M. and Musa, M. (2013). International business negotiations outcome and Performance in Tanzania. Unpublished Thesis.

10. Burhan, A. M., Ndimbwa, T. and Mihanjo, B. (2013) Understanding The Behavior Similarities And Differences Between The Upcoming Generations Of Tanzanian And Chinese Managers In International Business Negotiations. Business Management Dynamics ISSN: 2047-7031.

11. Burns, N. \& Grove, S.K. (1997) The Practice of Nursing Research Conduct, Critique, \& Utilization. W.B. Saunders and Co. Philadelphia.

12. business negotiations (pp. 369-382). London: Elsevier Science Ltd.

13. Cavusgil, S. T., \& Ghauri, P. N. (1990). Doing business in developing countries: Entry and negotiation strategies. London: Routledge.

14. Chen, G. B. (1996). Negotiating with the Chinese. UK: Dartmouth Publishing Co, Ltd.

15. Child, J., \& Stewart, S. (1997). Regional difference in China and their implications for Sinoforeign joint ventures. Journal of General Management, 23(2), 65-86. 
INTERNATIONAL JOURNAL OF ACADEMIC RESEARCH IN BUSINESS AND SOCIAL SCIENCES Vol. 8, No. 12, Dec, 2018, E-ISSN: 2222-6990 @ 2018 HRMARS

16. Deetz, S. (1996) "Describing Differences in Approaches to Organization Science: Rethinking Burrell and Morgan and their Legacy," Organization Science (7:2), pp. 191-207

17. Deverge, M. (1986). Negotiating with the Chinese. Euro-Asia Business Review, 5(1), 34-36.

18. Doktor, R., Tung, R. L., \& Glinow, A. V. (1991). Incorporating international dimensions in management theory building. Academy of Management Review, 16, 259-261.

19. Eiteman, E. (1990). American executives perceptions of negotiating joint ventures with the People's Republic of China: Lessons learned. Columbia Journal of World Business, Winter, 5967.

20. Gephart,R.(1999) Paradigms and Research Methods: http://division.aomonline.org/rm/1999.RMDForum Paradigms-and- Research. Accessed January 2009.

21. Graham, J. (1996). Vis-a`-vis: International business negotiation. In P. Z. Ghauri, \& J. C. Usunier (Eds.), International business negotiations (pp. 69-90). London: Pergamon, Elsevier Science Ltd.

22. Graham, J. L., Mintu, A. T., \& Rodgers, W. (1994). Explorations of negotiation behaviors in ten foreign cultures using a model developed in the United States. Management Science, 40(1), 72-95.

23. Hair, J.F., Black, W.C., Babin, B.J., \& Anderson, R.E. (2010). Multivariate Data Analysis. Seventh Edition. Prentice Hall, Upper Saddle River, New Jersey

24. Hall, P. (1986). The etic-emic distinction: Its observational foundation. In: B. R. Darvin, \& M. J. Voigt (Eds.), (pp. 123-151) Progress in communication sciences, 7.

25. Harris, S. (2000). Reconciling positive and interpretative international management research: A native category approach. International Business Review, 9, 755-770.

26. Heiba, F. (1984). International business negotiations: a strategic planning model. International Marketing Review, Autumn/Winter, 5-16.

27. Hofstede, G., \& Usunier, J. (1996). Hofstede's dimensions of culture and their influence on international business negotiation. In P. Ghauri, \& J. Usunier (Eds.), International business negotiations (pp. 119-129). London: Pergamon.

28. Shivji, I. G. (1974) The Silent Class Struggle. Dar es Salaam: Tanzania Publishing House.

29. Jeswald, W. S. (2003). The Global Negotiator. Making, Managing, and Mending Deals Around the World in the Twenty-First Century. Palgrave Macmillan.

30. Julius, K. N. (1973) Freedom and Development (Uhuru Na Maendeleo). A Selection from Writings and Speeches. Oxford University Press.

31. Kamukwamba, M. (2000) From bi-national organisation's trade unions alliance to the establishment of joint industrial relations collective bargaining mechanism: The case of Tanzania Zambia Railway Authority01cv. (http://www.global-labour university.org/fileadmin/GLU_conference_2011/papers/Mwansa_Kamukwamba.pdf)

32. Kirkbride, P. S., \& Tang, F. Y. (1990). Negotiation: Lessons from behind the bamboo curtain. Journal of General Management, 16(1), 1-13.

33. Kirkbride, P. S., Tang, F. Y., \& Westwood, R. I. (1991). Chinese conflict preferences and negotiation behavior: Cultural and psychological influences. Organizational Studies, 12(3), 365-386. 
INTERNATIONAL JOURNAL OF ACADEMIC RESEARCH IN BUSINESS AND SOCIAL SCIENCES

Vol. 8, No. 12, Dec, 2018, E-ISSN: 2222-6990 @ 2018 HRMARS

34. Kock, N. and Lynn, G. S. (2012). "Lateral Collinearity and Misleading Results in Variance-Based SEM: An Illustration and Recommendations," Journal of the Association for Information Systems: Vol. $\quad$ 13: ISS. Available at: http://aisel.aisnet.org/jais/vol13/iss7/2

35. Kreisberg, P. H. (1994). China's negotiating behaviour. In T. W. Robinson, \& D. Shambaugh (Eds.), Chinese foreign policy: Theory and practice (pp. 453-477). Oxford: Clarendon Press.

36. Kweka, J. \& Mboya, P. (2004). "Regional Integration and Poverty: The Case of Tanzania." Economic and Social Research Foundation (ESRF). Dar es Salaam, Tanzania.

37. Lavin, F. (1994). Negotiating with the Chinese. Foreign Affairs, July/August, 17-22.

38. Lewicki, R. J., Litterer, J. A., Minton, J. W., \& Saunder, D. M. (1994). Negotiation (2nd ed.). Burr Ridge,IL: Irwin.

39. Likert, R. 1932. A technique for the measurement of attitudes. Archives of Psychology, 22(140), 1-55.

40. Mayfield, J., Mayfield, M., Martin, P., \& Herbig, P. (1998). How location impacts international business negotiations. Review of Business, Winter, 21-24.

41. Myers, M. D. (1997). Interpretive research in information systems. In J. Mingers \& F. A. Stowell (Eds.), Information systems: An emerging discipline? (pp. 239-266). London: McGraw-Hill.

42. Paik, Y. S., \& Tung, R. L. (1999). Negotiating with East Asians: How to attain "win-win" outcomes. Management International Review, 39(2), 103-122.

43. Patton, M. Q. (1982). Practical evaluation. Beverly Hills: Sage.

44. Patton, M. Q. (1999). Qualitative evaluation and research methods. Newbury Park: Sage.

45. Phatak, A. V., \& Habib, M. H. (1996). The dynamics of international business negotiations. Business Horizons, 39(3), 30-38.

46. Pye, L. (1982). Chinese commercial negotiating style. Cambridge: Gunn \& Hain Publishers.

47. Ralston, D. A., Yu, K. C., Wang, X., Terpstra, R. H., Gustafson, D. J., \& He, W. (1996). The cosmopolitan Chinese manager: Findings of a study on managerial values across the six regions of China. Journal of International Management, 2, 79-107.

48. Schlevogt, K. (2000). Doing business in China I: Getting to know the next century's superpower. Thunderbird International Business Review, 42(1), 85-111.

49. Shenkar, O. (1993). The People's Republic of China. In R. B. Peterson (Ed.), Managers and national culture. London: Quorum Books.

50. Shenkar, O., \& Ronen, S. (1987). The Cultural context of negotiations: The implications of Chinese interpersonal normal. The Journal of Applied Behavioral Science, 23(2), 263-275.

51. Shenkar, O., \& Von Glinow, M. A. (1994). Paradoxes of organizational theory and research: Using the case of China. Management Science, 40(1), 56-71.

52. Shi, X. (2001). Antecedents of international business negortations in the China context. Management International Review, 41(2).

53. Shi, X., \& Westwood, R. I. (2000). International business negotiations in the Chinese context. In J. T. Li, A. Tsui, \& E. Weldon (Eds.), Management and organizations in Chin. NY: Macmillan.

54. Swecker, P. (1998). Validation of organizational practice in the Indonesian environment. Unpublished DBA thesis, Murdoch University, Perth, Western Australia. 
55. Triandis, H. C., Vassiliou, V., Vassiliou, G., Tanaka, Y., \& Shanmugan, A. V. (1972). The analysis of subjective culture. New York: John Wiley.

56. Trochin., W.M.K. 2006. Research methods knowledge base. [Onliine]. Available: www.socialresearchmethods.net [Accessed: September 2011]

57. Tse, D. K., Francis, J., \& Walls, J. (1994). Cultural differences in conducting intra- and intercultural negotiation: A Sino-Canadian comparison. Journal of International Business Studies, Third Quarter,537-555.

58. Tung, R. L. (1982). US-China trade negotiations: practices, procedures and outcomes. Journal of International Business Studies, Fall, 25-37.

59. Tung, R. L. (1994). Strategic management thought in Asia. Organizational Dynamics, 22(4), 5565.

60. Tung, R. L. (1996). Negotiating with East Asians. In P. Ghauri, \& J. C. Usunier (Eds.), International Unwin.

61. Walsham, G. (1993) Interpreting Information Systems in Organizations, Wiley, Chichester, UK,

62. Walter Rodney (1971) Some Implications of the Question of Disengagement from Imperialism. Tanzania Publishing House.

63. Weiss, R. (1994). Learning from strangers, the art and method of qualitative interviewing. New York: Free Press.

64. Willis, J. (1995). A Recursive, Reflective Instructional Design Model Based on Constructivist Interpretivist Theory. Educational Technology, 35(6):5-23.

65. Xie, J. L. (1995). Research on Chinese organizational behavior and human resource management: Conceptual and methodological considerations. In S. B. Prasad (Ed.), (pp. 1542). Advances in International Comparative Management, 10.

66. Xinping, S. and Wright, P. C. (2000). National Feelings on Business Negotiations: A Study in the China http://202.116.197.15/cadalcanton/Fulltext/21350 $2014319101820265 . p d f$

Context

67. Yang, J. Z. (1998). Key success factors of multinational firms in China. Thunderbird International Business Review, 40(6), 633-668.

68. Zhang, X. (1995). International business negotiations: Principles, methods and arts. Shanghai: Shanghai Joint Publishing Co in Chinese

69. Zikmund, W.G., Babin, B. J., Carr, J.C. \& Griffin, M. (2010). Business research methods. $8^{\text {th }}$ edition. Singapore: South-Western Cengage Learning. 